\title{
Analysis of the possibility of determining the general characteristics using the operational data of a vehicle engine
}

\begin{abstract}
The paper presents an analysis of the possibility of determining the general characteristics using the operational data of an engine of refuse collection vehicle. Data acquisition was done by reading information from the CAN network using FMS standard (Fleet Management System), which is widely used in heavy duty vehicles since year 2002. The paper presents the analysis of the expected measurement uncertainties resulting from the standard PN_ISO 15550-2009. The experimental data were filtered due to the established constraints that define the static states of the engine. On the basis of the obtained measurement data, corresponding to various defined static states, the general characteristics of the engine were made and discussed.
\end{abstract}

Key words: combustion engine, general characteristics, fuel consumption, tests in dynamic states, CAN bus

\section{Introduction}

The general characteristics of the engine include information about the regions of the engine's operating area that are most efficient, where specific fuel consumption reaches the smallest values. Economic operation based on those characteristics can contribute to a significant reduction of fuel consumption and consequently less pollutant emissions and lower costs. While the driver of a utility vehicle has a main impact on the fuel consumption during regular operation $[6,7,10-12]$, the power take-off unit (PTO), such as the garbage truck's propulsion system, is determined by the characteristics of the driven machine. It has been shown in the paper [8] that an appropriate configuration of the drive system based on the general characteristics of the engine reduces the fuel consumption of the utility vehicle by up to $35 \%$. Unfortunately, the information provided by the engine manufacturers contains only external characteristics and can not be used to determine the PTO performance, where the maximum received torque is several times lower then nominal. This introduces the need to determine the general characteristics using a chassis dynamometer for utility vehicles, what causes many problems and costs.

This paper presents the analysis of the possibility of determining the general characteristics using the operational data of a vehicle engine for the refuse collection vehicle. Data logging is possible by reading information from the FMS (Fleet Management System) standard, which has been widely used in heavy duty vehicles since 2002. It contains, among others: engine speed, torque, instantaneous fuel consumption. Data acquisition does not require interfering with the vehicle's onboard systems, just plug into a cab specially prepared by the manufacturer interface and record the data in real time to the storage it for later processing. By using this method, it is expected that the vast majority of data match the dynamic operation of the engine.

There are some differences in engine performance that work in dynamic states and those understood as static [13, 15]. Emerging operating conditions will be a consequence of long-term changes in the temperature of the engine components (e.g. warm-up after start-up) or engine operation at ambient temperatures significantly different from the average (e.g. winter operating conditions) and load and engine rapid changes [4, 9, 14]. For example, a spark ignition engine equipped with a typical three-function catalytic converter with oxygen sensor operating in a closed fuel delivery control loop emits more $\mathrm{CO}$ and $\mathrm{HC}$ during warm-up and cold start than in the operating phase when the thermal conditions are static. If the ambient temperature drops below $0^{\circ} \mathrm{C}$, the above effect will be magnified.

Under such conditions it is necessary to enrich the air/fuel mixture due to the low efficiency of the evaporation process. This significantly diminishes or prevents the catalytic converter from working properly, resulting in increased $\mathrm{CO}$ and $\mathrm{HC}$ emissions. The low temperature of the engine components also lowers the engine's thermal efficiency due to increased heat exchange and reduced mechanical efficiency due to increased viscosity of the lubricating oil. Reduced engine operating temperature causes also difficulty with ignition of the mixture. The above described phenomena related to the thermal state of the engine and the parameters of its operation can be also applied to the compression ignition engines. In this case, the unfavorable phenomenon of excessive particulate matter emissions in the exhaust gases is also observed.

\section{Static state of an engine operation}

Static states are defined in theoretical way as conditions of engine operation, where the successive cycles in each cylinder are fully repeatable [1]. Those terms describe the following equations:

$$
\begin{aligned}
& \mathrm{p}(\mathrm{V})=\text { idem } \\
& \mathrm{q}(\mathrm{V})=\text { idem }
\end{aligned}
$$

where: $\mathrm{p}$ - pressure in the cylinder, $\mathrm{q}$ - heat transfer between the working medium and the walls of the combustion chamber, V - instantaneous volume of the working medium.

The above conditions can not in fact be fulfilled due to the random conditions of engine cycles [16]. 
According to the Polish Standard [17] static states can be considered as torque and rotational speed changes within the permissible limits (Table 1). The range of permissible variations of engine performance such as particulate matter emissions, temperature and air pressure, exhaust gas, etc. are also specified.

Table 1. Acceptable deviations of the measured engine parameters acc. [17]

\begin{tabular}{|l|c|}
\hline Parameter & Permissible deviation \\
\hline Torque & $\pm 2 \%$ \\
\hline Engine speed & $\pm 2 \%$ \\
\hline Power & $\pm 3 \%$ \\
\hline Fuel consumption & $\pm 3 \%$ \\
\hline Specific fuel consumption & $\pm 3 \%$ \\
\hline
\end{tabular}

In addition, according to the Polish Standard [18], permissible fuel consumption deviations $\Delta G_{e}$ and engine power deviation $\Delta P$ should satisfy the following relation:

$$
\sqrt{\Delta \mathrm{G}_{\mathrm{e}}^{2}+\Delta \mathrm{P}^{2}} \leq 3 \%
$$

However, the standard does not define the time, in which the specified deviations must be kept to conclude the engine is operating in the static state.

In his work [3, 5], Chłopek presented a detailed description of the concept of selection of operating conditions into static and dynamic, taking into account the real possibility of carrying out tests of internal combustion engines. The author considered that the measurement signal, before using it to classify the operating conditions of the engine, should be filtered using low pass filters with a prescribed stop frequency to remove from the recorded waveform measurement errors and accidental errors. The author pointed out that the classification of the operating conditions of the engine to static, when the derivative of the observed signal is equal to zero, in the real test conditions is too strict criteria. The author suggested for laboratory practice, as a criterion for qualifying operating conditions to static, that the derivative of observed signal is less than the assumed limit value. The operating state can then be specified as static with declared accuracy. Selection of limit values for such classification will be determined by the objectives set for the planned study.

\section{Data logging using CAN bus}

The engine speed is measured in the vehicle by an inductive sensor located at the flywheel, which records changes in the magnetic field generated by the teeth distributed around the edge of the flywheel. According to the FMS standard, the engine speed is measured every 20 ms with a resolution of $0.125 \mathrm{rpm}$. For a minimum engine speed of $600 \mathrm{rpm}$, a resolution of $\pm 0.0625 \mathrm{rpm}$ corresponds to a deviation of $\pm 0.01 \%$ of the measuring instrument. The torque is read with an accuracy of $1 \%$ of the maximum torque of the motor. For the analyzed engine it is $1400 \mathrm{~N} \cdot \mathrm{m}$, so the signal resolution is $\pm 14 \mathrm{~N} \cdot \mathrm{m}$. Therefore, only indications of over $700 \mathrm{~N} \cdot \mathrm{m}$ meet the measurement requirements of the Polish Standard [17] with a permissible measuring deviation of less than $2 \%$. The fuel consumption is determined based on the injector opening time and is read with an accuracy of $\pm 0.025 \mathrm{dm}^{3} / \mathrm{h}$. Again, values greater than $0.833 \mathrm{dm}^{3} / \mathrm{h}$ should be taken into account in order not to exceed the deviations defined in [17]. This does not, however, introduce real boundaries, because fuel consumption during idle runs at $3 \mathrm{dm}^{3} / \mathrm{h}$, so in the extreme cases the deviation is only $\pm 0.83 \%$. A summary of the measuring deviations of the instruments when recording CAN data is presented in Table 2.

Table 2. Measuring deviation values of the instruments when recording data from the CAN bus

\begin{tabular}{|l|c|}
\hline Parameter & Deviation \\
\hline $\mathrm{n}$ & $\leq \pm 0.01 \%$ \\
\hline $\mathrm{M}$ & $\leq \pm 2 \%($ for $\mathrm{M}>700 \mathrm{~N} \cdot \mathrm{m})$ \\
\hline $\mathrm{Ge}$ & $\leq \pm 0.83 \%$ \\
\hline
\end{tabular}

For such restrictions, the condition of formula (3) is satisfied:

$$
\sqrt{0.83^{2}+2^{2}}=2.17 \leq 3 \%
$$

It can be concluded, that using CAN bus data logging it is practically impossible to make measurements of engine performance according to Polish Standard [17] due to the low resolution of the recorded torque value in the full field of the engine operation. Consequently, in the further analysis, the limitation shown in Table 2 will be not applied, allowing the increase of torque measurement error.

\section{Determination of the general characteristics of the engine}

The data from $8 \mathrm{~h} 46 \mathrm{~min}$ of refuse vehicle's engine operation was taken into account [20]. The information about engine speed $n$, torque $M$ and fuel consumption $G_{e}$ was sampled every $20 \mathrm{~ms}$. Due to high number of measuring points per second, a lowpass filter was applied. Torque and engine speed values was computed using MATLAB function cheby1, which is Chebyshev Type 1 filter. Function parameters such as Rp and Wp were set as 10 and 0.11 respectively, both for torque and engine speed. The result of filtration is shown in the Fig. 1.

Searching for static states during daily operation of truck's engine it is crucial to determine the length of time period $\mathrm{T}$, in which the engine's parameters do not change, or at least do not change more than assumed values. As long as the specific value of time is neither defined by the norm [17] nor the literature, five $\mathrm{T}$ values were proposed (static state duration):

$$
\mathrm{T}=\{0.5,1,2,3,4\}[\mathrm{s}]
$$

Each measuring point $i$ in time $s_{i}$ were examined locally by defining a time period $t$ with a span equal to the $T$ value:

$$
\mathrm{t} \in\left(\mathrm{s}_{\mathrm{i}}-\frac{\mathrm{T}}{2} ; \mathrm{s}_{\mathrm{i}}+\frac{\mathrm{T}}{2}\right)
$$

With $50 \mathrm{~Hz}$ signal sampling each t period corresponds to $\mathrm{N}$ number of measuring points:

$$
N=\{26,50,100,150,200\}
$$

For further investigations it is needed to describe following quantities: 


$$
\begin{gathered}
j \in\left(i-\frac{N}{2} ; i+\frac{N}{2}\right) \\
M_{j}=\left\{M_{i-\frac{N}{2}}, M_{i-\frac{N}{2}+1}, \ldots, M_{i}, \ldots, M_{i+\frac{N}{2}-1}, M_{i+\frac{N}{2}}\right\} \\
n_{j}=\left\{n_{i-\frac{N}{2}}, n_{i-\frac{N}{2}+1}, \ldots, n_{i}, \ldots, n_{i+\frac{N}{2}-1}, n_{i+\frac{N}{2}}\right\}
\end{gathered}
$$

where: $M_{i}$ - value of torque in point $i, n_{i}$ - value of engine speed in point $i, M_{j}-$ value of torque in point $j, n_{j}-$ value of engine speed in point $\mathrm{j}$.

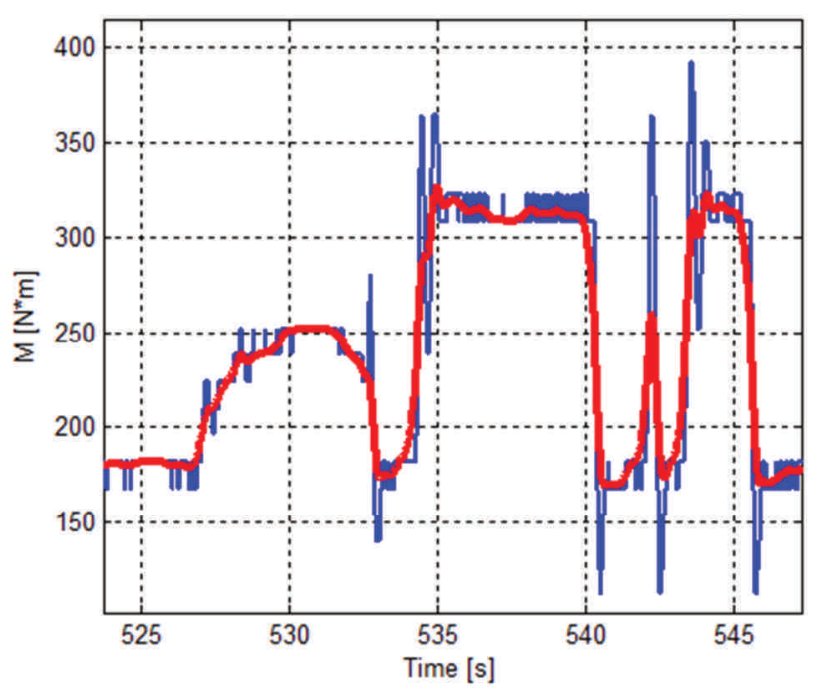

In terms of torque and engine speed values, to determine engine static state two conditions were proposed. First condition derives from norm [17] and specifies that any of $\mathrm{M}_{\mathrm{j}}$ and $\mathrm{n}_{\mathrm{j}}$ values within $\mathrm{t}$ period should not differ more than $\pm 2 \%$ of values $M_{i}$ and $n_{i}$ :

$$
\left\{\begin{array}{c}
\left|M_{i}-M_{j}\right| \leq 2 \% \cdot M_{i} \\
\left|n_{i}-n_{j}\right| \leq 2 \% \cdot n_{i}
\end{array}\right.
$$

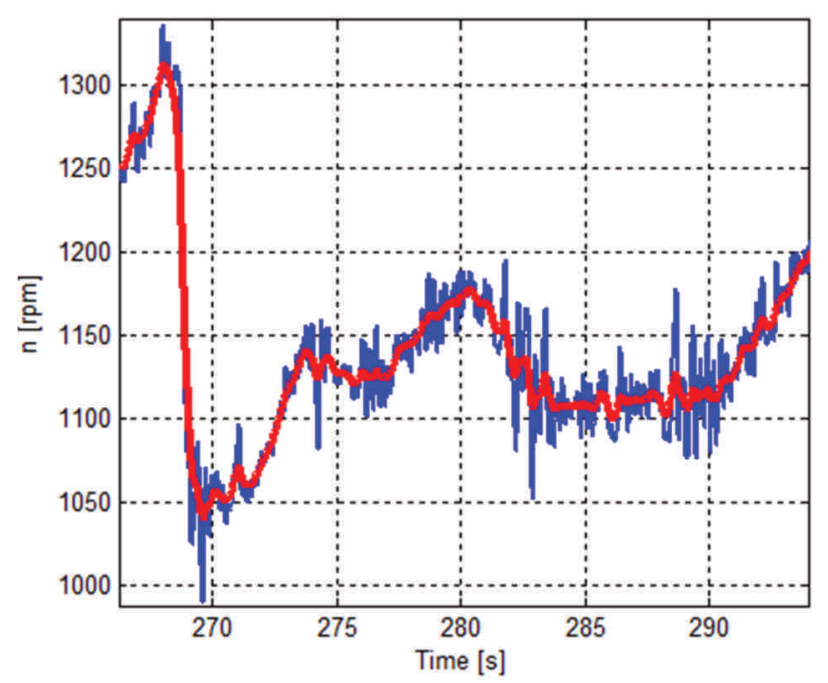

Fig. 1. Measuring points of engine speed (n) and torque (M) before (blue) and after filtration (red)

It is impossible to obtain constant values of parameters in real conditions, but their fluctuation can be examined. Second condition specifies the maximum derivatives of functions in examined point $i$ [5]:

$$
\left\{\begin{array}{l}
\left|\frac{\delta \mathrm{M}_{\mathrm{i}}}{\delta \mathrm{t}}\right|<\mathrm{M}_{\max }^{\prime} \\
\left|\frac{\delta \mathrm{n}_{\mathrm{i}}}{\delta \mathrm{t}}\right|<\mathrm{n}_{\max }^{\prime}
\end{array}\right.
$$

Using the least square method, the linear functions were computed as approximations of $\mathrm{M}_{\mathrm{j}}$ and $\mathrm{n}_{\mathrm{j}}$ points. To fit the curves, the polyfit MATLAB function was used. As a results, two linear functions describing parameter's change in proximity of point $\mathrm{i}$ were obtained:

$$
\left\{\begin{aligned}
\left.M(t)\right|_{i} & =a_{1}^{M} \cdot t+a_{0}^{M} \\
\left.n(t)\right|_{i} & =a_{1}^{n} \cdot t+a_{0}^{n}
\end{aligned}\right.
$$

The second condition for operation in steady state can be then expressed by the following relations:

$$
\left\{\begin{array}{l}
\left|\mathrm{a}_{1}^{\mathrm{M}}\right|<\mathrm{M}_{\max }^{\prime} \\
\left|\mathrm{a}_{1}^{\mathrm{n}}\right|<\mathrm{n}_{\max }^{\prime}
\end{array}\right.
$$

Four maximum derivative values were examined (derivative limits):

$$
\left\{\begin{array}{l}
\mathrm{M}_{\max }^{\prime}=\{5,10,15,20\}\left[\frac{\mathrm{N} \cdot \mathrm{m}}{\mathrm{s}}\right] \\
\mathrm{n}_{\max }^{\prime}=\{5,10,15,20\}\left[\frac{\mathrm{rpm}}{\mathrm{s}}\right]
\end{array}\right.
$$

Graphical interpretation of the two conditions is shown in the Fig. 2.
Both conditions should be fulfilled simultaneously for engine speed and torque. First one examines the distribution of measuring points over the analyzed period $\mathrm{T}$, the second defines tendency of the parameter change. It should be pointed that $\pm 2 \%$ criterion is dependent on the value in specified point, which means the higher the value the wider limit's span. Measuring points, which do not fulfil the criteria were removed from data set. In Fig. 3 example of points selection corresponding to the static state has been shown. 5 values of $\mathrm{T}$ and 4 values of $\mathrm{M}_{\max }^{\prime}$ and $\mathrm{n}_{\max }^{\prime}$ were examined, which gives 20 combinations of analyzed criteria. As a result 20 sets of data with $M, n$ and $G_{e}$ were computed, each corresponding to assumed static state. Additionally, some of measuring points were removed from data sets. Minimum fuel consumption of examined engine while idling was calculated as $3.03 \mathrm{l} / \mathrm{h}$. Thus, points for $\mathrm{G}_{\mathrm{e}}$ less than $3 \mathrm{dm}^{3} / \mathrm{h}$ were not considered.

The next step of the analysis was to obtain fuel consumption and specific fuel consumption map. Due to the fact that measuring points distribution over the area of operation of the engine is not uniform, surface approximation was applied. Surface fitting was performed via MATLAB function fit, which creates a surface fit to the data in vectors $M, n$ and $G_{e}$. Using the least square method, polynomial surface of degree 5 in $\mathrm{M}$ and $\mathrm{n}$ direction was assumed.

Computed polynomial coefficients allowed calculation of $G_{e}$ value in each point in defined engine operation area A, which is a grid with uniformly distributed points in its range: 


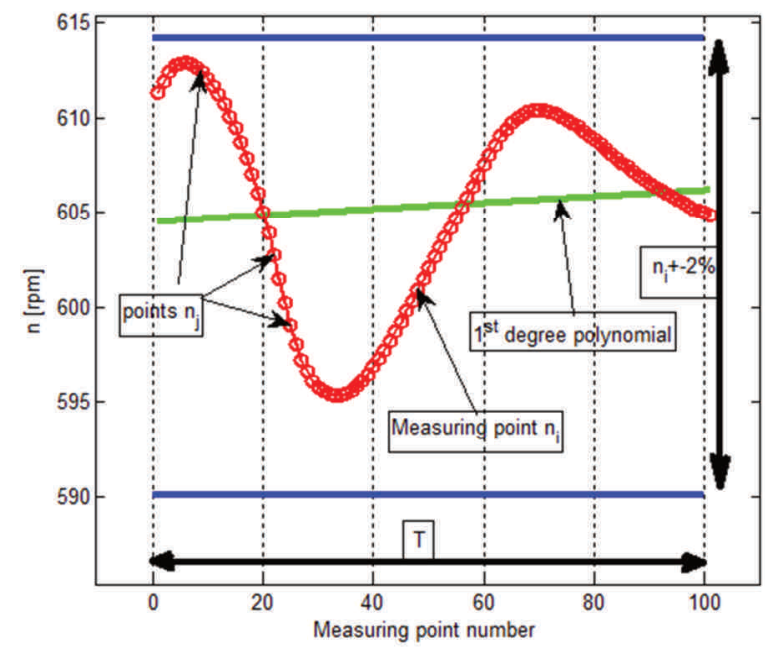

Fig. 2. Interpretation of two static state conditions for engine speed: blue lines - limit of $2 \%$ variation, green line - derivative of the approximation function

$$
\{\mathrm{M}, \mathrm{n}\} \subset \mathrm{A}
$$

for:

$$
\begin{gathered}
\mathrm{M}=\left\{\mathrm{M}_{\text {min }}, \begin{array}{c}
\mathrm{M}_{\text {min }}+1, \mathrm{M}_{\text {min }}+2, \ldots, \mathrm{M}_{\text {max }}-2, \mathrm{M}_{\text {max }} \\
\left.-1, \mathrm{M}_{\text {max }}\right\}
\end{array}\right. \\
\mathrm{n}=\left\{\mathrm{n}_{\text {min }}, \mathrm{n}_{\text {min }}+1, \mathrm{n}_{\min }+2, \ldots, \mathrm{n}_{\text {max }}-2, \mathrm{n}_{\max }\right. \\
\left.-1, \mathrm{n}_{\max }\right\}
\end{gathered}
$$

where: $\mathrm{n}_{\min }, \mathrm{M}_{\min }, \mathrm{n}_{\max }, \mathrm{M}_{\max }-$ minimum and maximum of speed and torque values in analyzed data set.

Since maximum engine power equals $208 \mathrm{~kW}$, the area above this value was removed from the map. Similarly, engine torque rises gradually from $700 \mathrm{~N} \cdot \mathrm{m}$ for $650 \mathrm{rpm}$ to its maximum value $1400 \mathrm{~N} \cdot \mathrm{m}$ for $1000-1350 \mathrm{rpm}$. Thus, points above mentioned line were removed as well.

Calculated values of $G_{e}$ over the area $A$ were used to calculate specific fuel consumption $\mathrm{g}_{\mathrm{e}}$ :

$$
\mathrm{g}_{\mathrm{e}}=\frac{\mathrm{G}_{\mathrm{e}}}{\mathrm{M} \cdot \mathrm{n}}
$$

As the lowest and highest value of $\mathrm{g}_{\mathrm{e}}$ on the map was assumed 170 and $280 \mathrm{~g} / \mathrm{kWh}$ respectively.

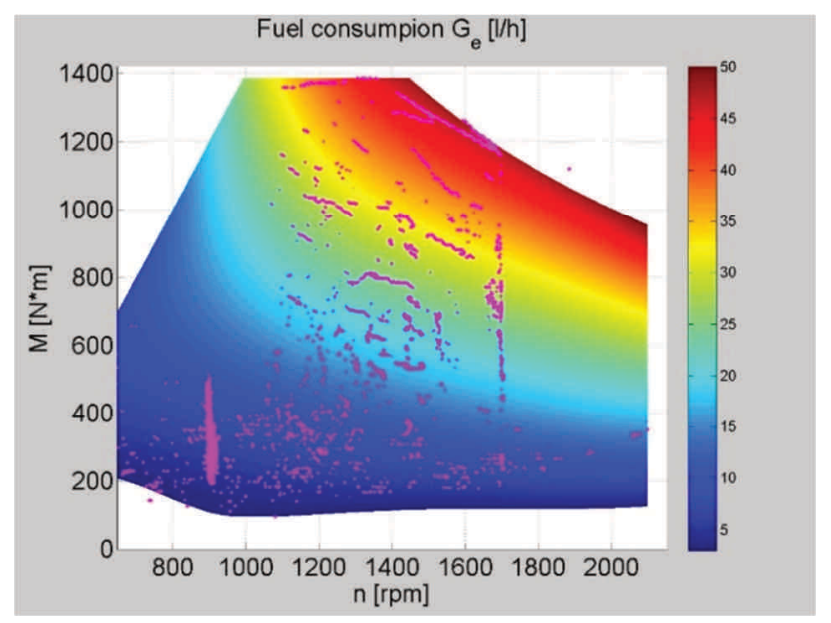

Fig. 4. Characteristics obtained from operational data: static state duration $0.5 \mathrm{~s}$; derivative limits: $20 \mathrm{~N} \cdot \mathrm{m} / \mathrm{s}, 20 \mathrm{rpm} / \mathrm{s}$

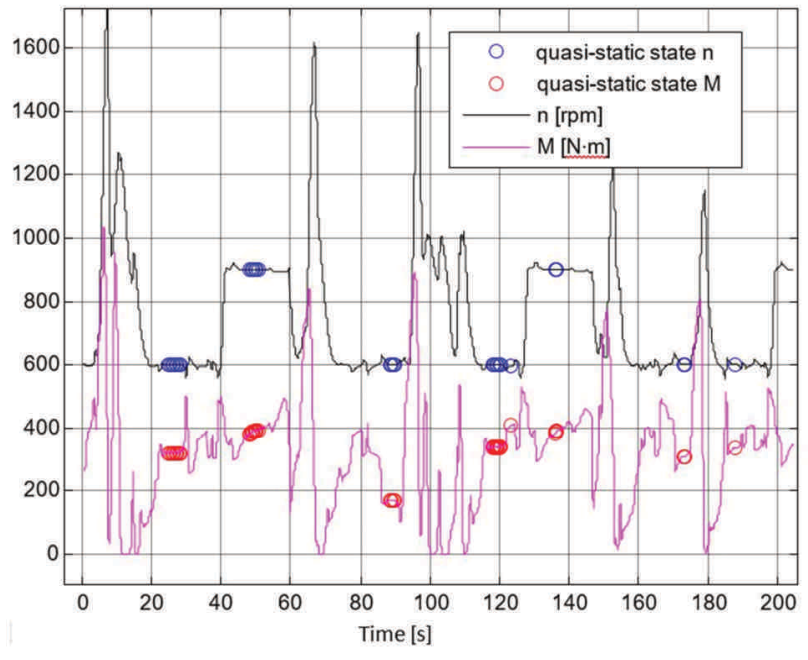

Fig. 3. Example of points selection corresponding to the static state; assumed minimum static state duration (T) 2 seconds

Finally applied algorithm for data selection and determining the general characteristics includes following steps:

- data filtering by lowpass cheby1 filter,

- definition of static state duration length $\mathrm{T}$ in point neighborhood,

- condition I: remove point if value in $\mathrm{T}$ domain differs more than $2 \%$ from value in point $\mathrm{i}$,

- condition II: compute $1^{\text {st }}$ degree polynomial curve in $\mathrm{T}$ domain. If its derivative is more than $\mathrm{M}^{\prime}$ (or n') remove the i point,

- remove points where $\mathrm{G}_{\mathrm{e}}<3 \mathrm{dm}^{3} / \mathrm{h}$,

- compute coefficients of polynomial fitting surface of $5^{\text {th }}$ degree,

- compute $G_{e}$ values for each point in uniformly distributed point grid in area $\mathrm{A}$,

- remove points due to maximum power and torque constrains from the grid/map,

- compute $g_{\mathrm{e}}$,

- remove points where $\mathrm{g}_{\mathrm{e}}<170$ and $\mathrm{g}_{\mathrm{e}}>280 \mathrm{~g} / \mathrm{kWh}$,

- draw $G_{e}$ and $g_{e}$ map.

Results of described analysis are shown in Figs 4-10.

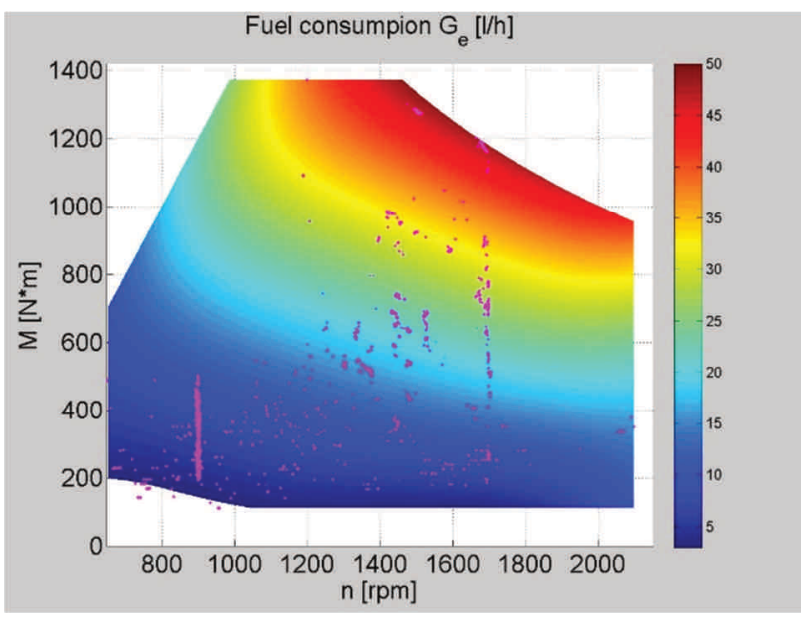

Fig. 5. Characteristics obtained from operational data: static state duration $0.5 \mathrm{~s}$; derivative limits: $5 \mathrm{~N} \cdot \mathrm{m} / \mathrm{s}, 5 \mathrm{rpm} / \mathrm{s}$ 


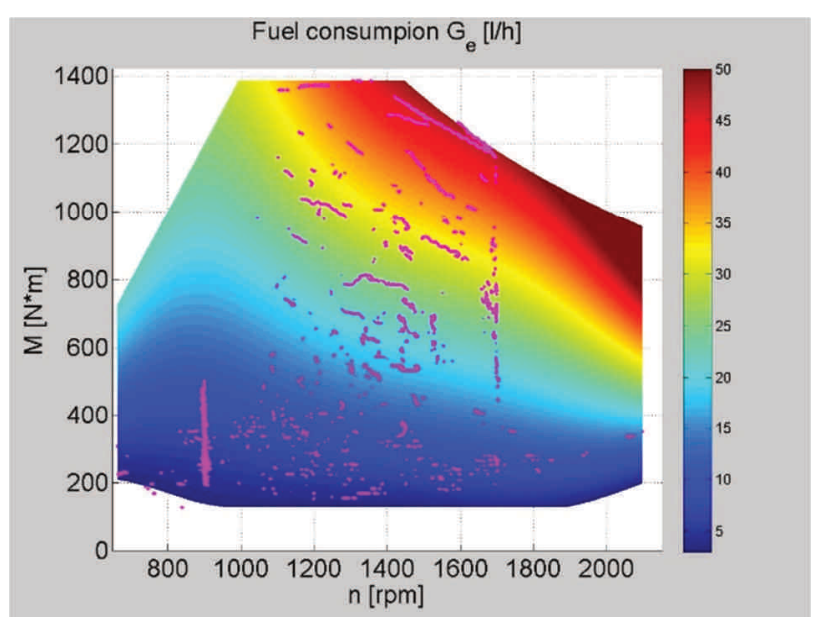

Fig. 6. Characteristics obtained from operational data: static state duration $1 \mathrm{~s}$; derivative limits: $20 \mathrm{~N} \cdot \mathrm{m} / \mathrm{s}, 20 \mathrm{rpm} / \mathrm{s}$

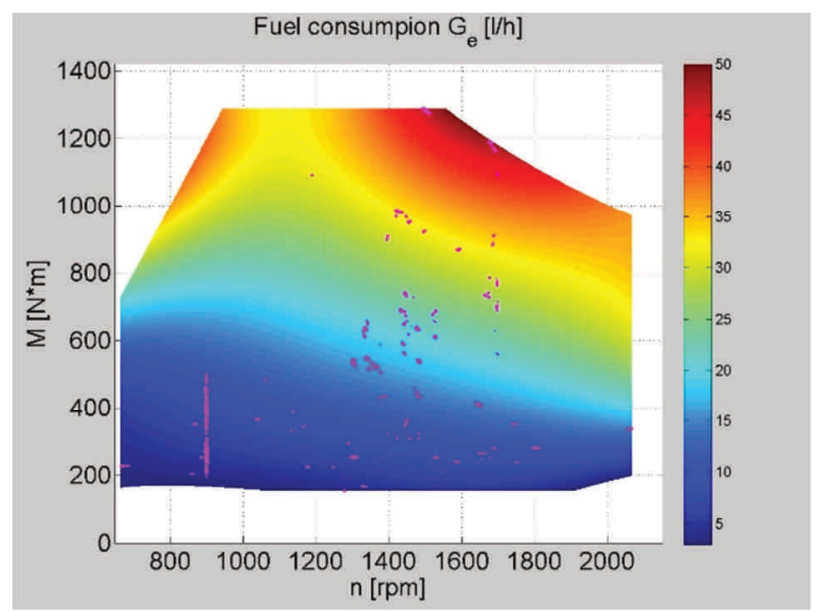

Fig. 8. Characteristics obtained from operational data: static state duration $2 \mathrm{~s}$; derivative limits: $5 \mathrm{~N} \cdot \mathrm{m} / \mathrm{s}, 5 \mathrm{rpm} / \mathrm{s}$

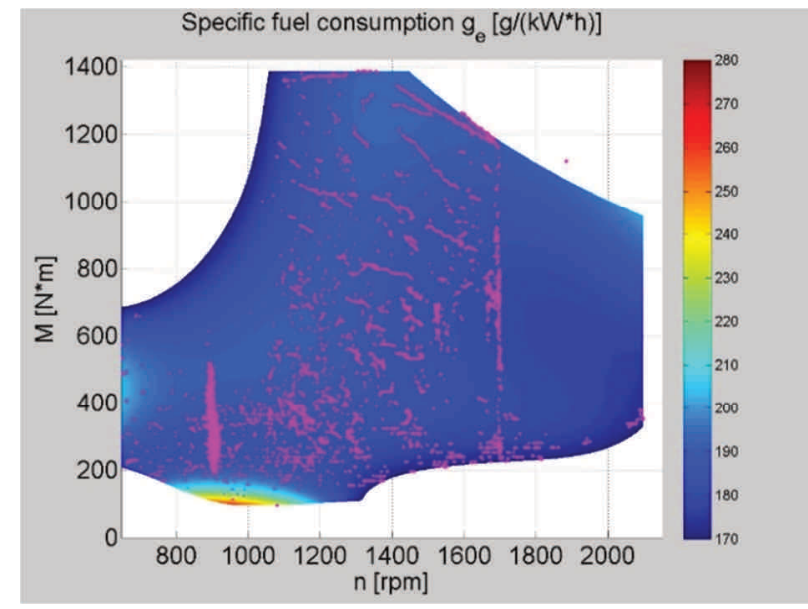

Fig. 10. General characteristics obtained from operational data: static state duration $0.5 \mathrm{~s}$; derivative limits: $20 \mathrm{~N} \cdot \mathrm{m} / \mathrm{s}, 20 \mathrm{rpm} / \mathrm{s}$

\section{Summary}

The results shown in Figs 4-10 show a good similarity in monotonicity of functions in adequate regions of operation field. The noticeable divergence between extremes results from the accepted static state duration limits (4) and the acceptable value of the signal derivative limits in the interval under consideration (14). Reducing the

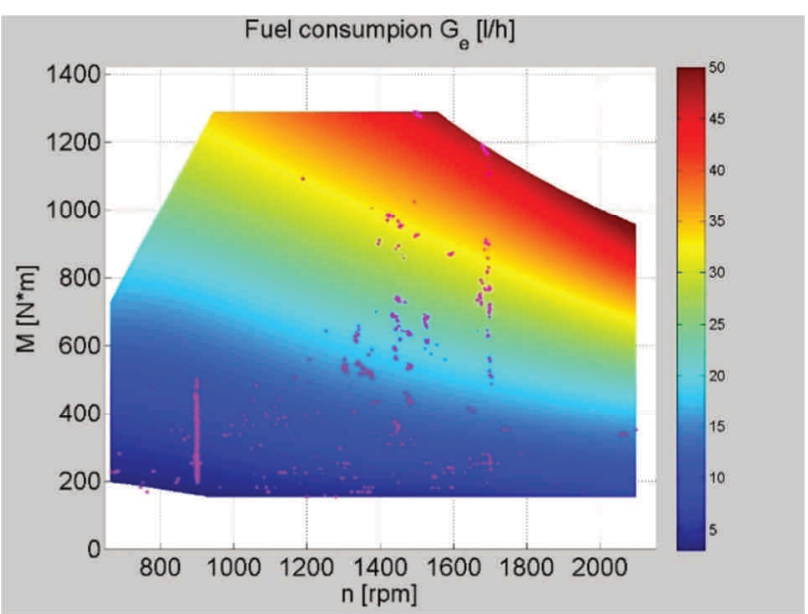

Fig. 7. Characteristics obtained from operational data: static state duration 1 $\mathrm{s}$; derivative limits: $5 \mathrm{~N} \cdot \mathrm{m} / \mathrm{s}, 5 \mathrm{rpm} / \mathrm{s}$

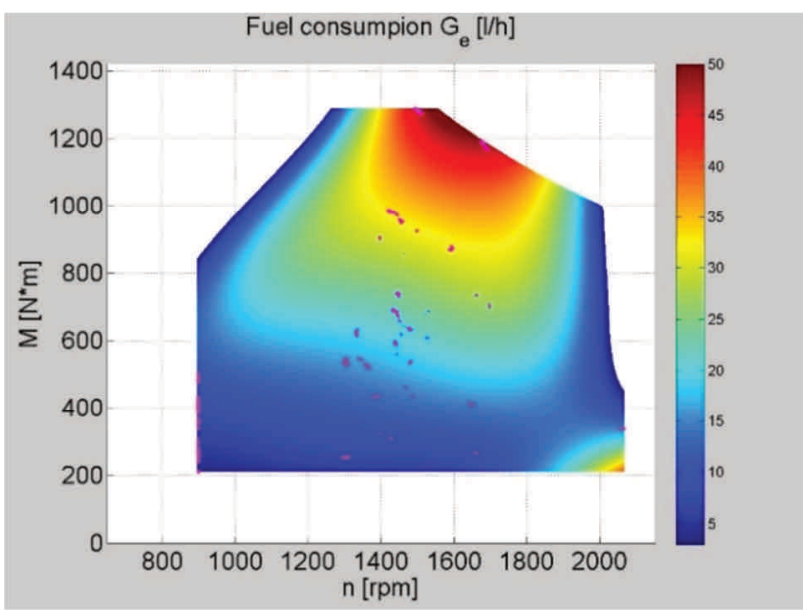

Fig. 9. Characteristics obtained from operational data: static state duration 4 $\mathrm{s}$; derivative limits: $5 \mathrm{~N} \cdot \mathrm{m} / \mathrm{s}, 5 \mathrm{rpm} / \mathrm{s}$

static state duration limits, as well as increasing the allowed value of the derivative of the signal in the interval in question, results in increasing the number of measurement points. On the other hand, the repeatability of engine operating conditions, theoretically defined by the same coordinates: torque - engine speed, is worse. In some cases artificially generated extrema (outside the tested engine operation area) is observed, which is the result of the high degree approximation function usage. It may be expected that the use of low degree polynomial functions will reduce the quality of the projection of the measurement data, but will eliminate the development of artificial extremes. It can be observed that tightening the selection criteria reduces the available points mainly in the area of low engine speeds and high torque values. At the same time, it can be seen that the number of points that have passed the selection is more sensitive to the allowed value of the signal derivative.

The next stage of the work will be defining the quantitative criteria of the quality of map generation using data from road tests. This analysis can be performed using stationary tests done for the same engine as in road tests. It is expected some guidelines to improve the quality of the mapping, e.g. by increasing the length of the input data set, will be worked out. 


\section{Bibliography}

[1] BERNHARDT, M., KRUCZYŃSKI, S. Praca silnika w warunkach nieustalonych, część I-VII. Technika Motoryzacyjna. 1982, 2-7.

[2] BIELACZYC, P., MERKISZ, J., SZCZOTKA, A. An Investigation of cold start and warm-up phases with a SI engine for meeting new European emissions regulations. Archiwum Motoryzacji. 1999, 1-2, 67-84.

[3] CHŁOPEK, Z., SZCZEPAŃSKI, T. Research concept of the combustion engines properties in dynamic states. Combustion Engines. 2013, 154(3), 168-174.

[4] CHŁOPEK, Z. Modelowanie procesów emisji spalin w warunkach eksploatacji trakcyjnej silników spalinowych. Oficyna Wydawnicza Politechniki Warszawskiej, Warszawa 1999.

[5] CHŁOPEK, Z. Some remarks on engine testing in dynamic states. Combustion Engines. 2010, 143(4), 60-71.

[6] CICHY, M., KROPIWNICKI, J., MAKOWSKI, S. Model silnika spalinowego w formie grafów wiązań $(\mathrm{GW})$. Silniki Spalinowe. 2004, 2, 40-47.

[7] CICHY, M., KROPIWNICKI, J. Wykorzystanie metody rozbiegu do określania dynamicznego momentu obrotowego silnika. Materiaty konferencji I Forum Młodych, ATR Bydgoszcz. 1998, 7-13.

[8] CZYŻEWICZ, J., KROPIWNICKI, J., WYSOCKI, O. Model of the hydraulic pump powertrain of refuse collection vehicle compaction mechanism. Combustion Engines. 2015, 626-630.

[9] DUARTE, G.O. et al. Establishing bonds between vehicle certification data and real-world vehicle fuel consumption a vehicle specific power approach. Energy Conversion and Management. 2015, 92, 251-265.
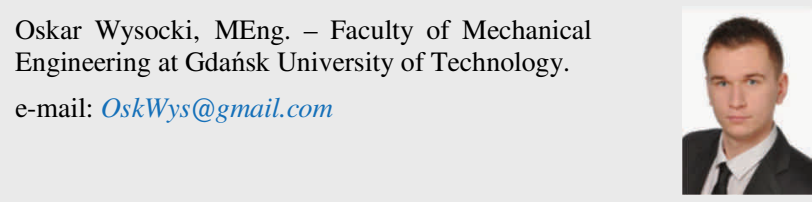

Jacek Czyżewicz, PhD. - Faculty of Mechanical Engineering at Gdańsk University of Technology.

e-mail:JacCzyze@pg.gda.pl
[10] FREY, H.C. et al. Comparing real-world fuel consumption for diesel- and hydrogen-fueled transit buses and implication for emissions. Transportation Research Part D. 2007, 12, 281-291.

[11] GAO, Z. et al. Drive cycle simulation of high efficiency combustions on fuel economy and exhaust properties in light-duty vehicles. Applied Energy. 2015, 157, 762-776.

[12] KROPIWNICKI, J., KNEBA, Z., ZIÓŁKOWSKI, M. Test for assessing the energy efficiency of vehicles with internal combustion engines. International Journal of Automotive Technology. 2013, 14(3), 479-487.

[13] LONGWIC, R. Charakterystyka działania silnika o zapłonie samoczynnym w warunkach swobodnego rozpędzania. Wydawnictwo Politechniki Lubelskiej. Lublin 2011.

[14] MERKISZ, J., ANDRZEJEWSKI, M., PIELECHA, J. The effect of applying the eco-driving rules on the exhaust emissions. Combustion Engines. 2013, 155(4), 66-74.

[15] $\mathrm{OH}, \mathrm{Y}$. et al. Modelling effect of vehicle specification on fuel economy based on engine fuel consumption map and vehicle dynamics. Transportation Research Part D. 2014, 32, 287-302.

[16] PIĘTAK, A. Diagnozowanie silników o ZS na podstawie przebiegu procesu przejściowego. Wydawnictwo Politechniki Poznańskiej 1998.

[17] PN-ISO 15550-2009.

[18] PN-ISO 3046-3.

[19] SZCZEPAŃSKI, T. Metoda oceny użytkowych właściwości silnika spalinowego w stanach dynamicznych. Rozprawa doktorska. Politechnika Warszawska 2015.

[20] WYSOCKI, O. Rekonstrukcja charakterystyki jednostkowego zużycia paliwa na podstawie obserwacji wybranych parametrów pracy silnika spalinowego $\mathrm{z}$ zapłonem samoczynnym. Praca dyplomowa magisterska. Politechnika Gdańska 2016.

Jacek Kropiwnicki, DSc., PhD. - Faculty of Mechanical Engineering at Gdańsk University of Technology.

e-mail:JKropiwn@pg.gda.pl 